\title{
The thermal diffusivity of molecular cryocrystals
}

\author{
V.V. Sumarokov ${ }^{1}$, A. Jeżowski ${ }^{2}$, P. Stachowiak ${ }^{2}$, and Yu.A. Freiman ${ }^{1}$ \\ ${ }^{1}$ B. Verkin Institute for Low Temperature Physics and Engineering of the National Academy of Sciences of Ukraine, \\ 47 Nauky Ave., Kharkov 61103, Ukraine \\ E-mail: sumarokov@ilt.kharkov.ua \\ ${ }^{2}$ W. Trzebiatowski Institute of Low Temperature and Structure Research, Polish Academy of Sciences, \\ P.O. Box 1410, 50-950 Wroclaw, Poland
}

Received November 12, 2018

\begin{abstract}
Low-temperature thermal diffusivity of molecular cryocrystals $\left(\mathrm{O}_{2}, \mathrm{~N}_{2}, \mathrm{CO}, \mathrm{N}_{2} \mathrm{O}\right.$ and $\left.\mathrm{CO}_{2}\right)$ has been investigated and some anomalies were found. The thermal diffusivity of these crystals vary by more than 4-6 orders of the magnitude in the temperature range from $1 \mathrm{~K}$ up to their triple points. The thermal diffusivity displays jumps at the phase transition points. It has been found that the thermal diffusivity of solid oxygen is nonmonotonic. Below $4 \mathrm{~K}$, the temperature dependence shows a plateau which is due to the fact that both the heat capacity and the thermal conductivity have the cubic temperature dependence in this temperature range. For the cryocrystals of the nitrogen group, a similar plateau is shifted to lower temperatures. The temperature dependence of the equalization time for these crystals is studied.
\end{abstract}

Keywords: thermal diffusivity, thermal conductivity, specific heat, density, molecular cryocrystals.

Thermal properties are important characteristics of substances. The heat capacity, thermal conductivity, and thermal diffusivity describe the rates of change in internal energy, heat propagation, and temperature changes in thermal processes in a substance. The first two properties are examined when the substance is in thermal equilibrium. In non-equilibrium thermal processes, the rate of temperature equalization over the substance is characterized by the thermal diffusivity [1]. Information on this property is important for cryogenic technology, in planning of lowtemperature experiments, in space research, etc. Here we present the temperature dependence of the thermal diffusivity of simple molecular cryocrystals: nitrogen $\left(\mathrm{N}_{2}\right)$, carbon monoxide $(\mathrm{CO})$, nitrous oxide $\left(\mathrm{N}_{2} \mathrm{O}\right)$, carbon dioxide $\left(\mathrm{CO}_{2}\right)$ and oxygen $\left(\mathrm{O}_{2}\right)$ at low temperatures.

Heat propagation in a substance in the absence of internal heat sources is described by the equation of thermal conductivity [2]

$$
\frac{\partial T}{\partial \tau}=a(T) \Delta T, \quad a(T)=\frac{k(T)}{\rho(T) C(T)},
$$

where $T$ is the temperature, $\tau$ is the time, $a$ is the thermal diffusivity coefficient, $\Delta$ is the Laplace operator, $k$ is the thermal conductivity coefficient, $\rho$ is the density and $C$ is the specific heat.

The temperature dependence of the thermal diffusivity of these substances were obtained using the experimental data on the density, the heat capacity and the thermal conductivity both our own [3-8] and literature data from Refs. 9-12. The resulting temperature dependences of the heat capacity, density, thermal conductivity and thermal diffusivity for oxygen crystal and for the $\mathrm{N}_{2}$-type solids are shown in Figs. 1-5.

The temperature dependence of the coefficient of thermal diffusivity of solid oxygen is shown in Fig. 1. The temperature dependences of the density, heat capacity, and thermal conductivity of solid oxygen [3,4,9-13] are also shown in Fig. 1. The temperature dependence $a(T)$ of solid oxygen is nonmonotonic. In low-temperature $\alpha$ and $\beta$ phases, the coefficient $a(T)$ decreases with increasing temperature. In $\gamma$ phase of crystalline oxygen, the thermal diffusivity increases with temperature, which is mainly due to an unusual behavior of the thermal conductivity - it increases with increasing temperature. In the vicinity of the phase transitions, jumps of the thermal diffusivity are observed. At $\gamma-\beta$ phase transition, the $a(T)$ undergoes an upward jump of $125 \%$. With further decrease of the temperature in the $\beta$ phase, the thermal diffusivity increases by about $100 \%$ which is due to the fact that the heat capacity in the $\beta$ phase increases with increasing temperature, whereas the thermal conductivity and the density do not vary significantly with temperature. At the temperature of $\beta-\alpha$ phase transition, the jump of $a$ exceeds $350 \%$. With further decrease of the temperature, the thermal diffusivity sharply increases and in the region of the maximum of the heat conductivity the growth slows down, where an inflection is observed and the curve attains a plateau which is due to the fact that in this temperature range 


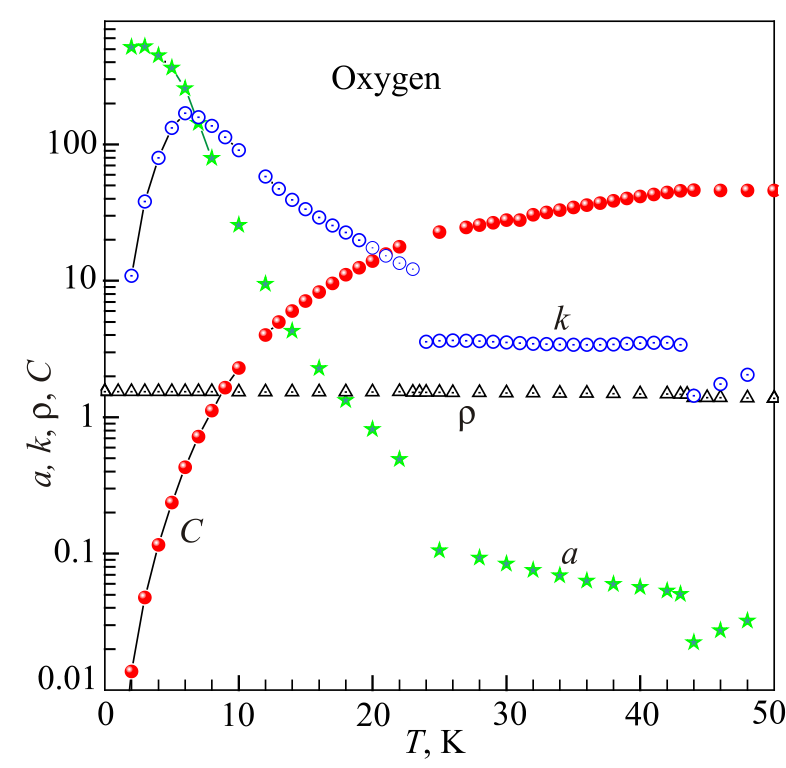

Fig. 1. (Color online) Temperature dependences of the thermal diffusivity $a\left[\mathrm{~cm}^{2} / \mathrm{s}\right]$, the thermal conductivity $k[\mathrm{~mW} /(\mathrm{cm} \cdot \mathrm{K})]$ $[3,4]$, the density $\rho\left[\mathrm{g} / \mathrm{cm}^{3}\right][9-13]$ and the heat capacity $C[\mathrm{~J} /(\mathrm{g} \cdot \mathrm{K})]$ [9-13] for crystalline oxygen.

dependences on temperature, both of the heat capacity and the thermal conductivity, vary according to a cubic law while the density is almost independent of the temperature.

Figure 2 shows the temperature dependences of the coefficient of thermal diffusivity $a(T)$ of solid nitrogen, as well as the literature data on the temperature dependences of the thermal conductivity [4,5], the density [9-13], and

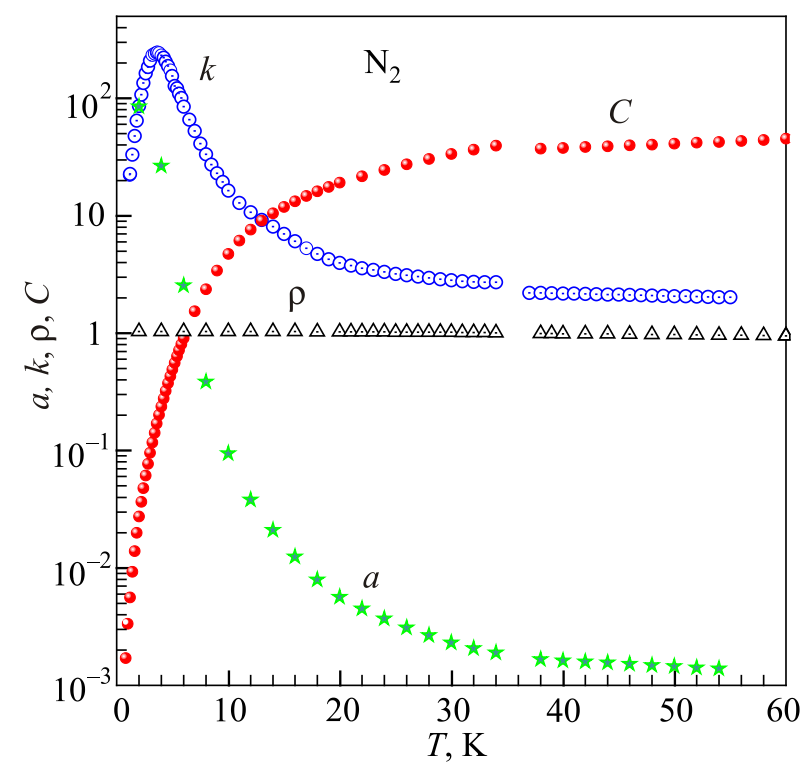

Fig. 2. (Color online) Temperature dependences of the thermal diffusivity $a\left[\mathrm{~cm}^{2} / \mathrm{s}\right]$, the thermal conductivity $k[\mathrm{~mW} /(\mathrm{cm} \cdot \mathrm{K})][4,5]$, the density $\rho\left[\mathrm{g} / \mathrm{cm}^{3}\right][9-13]$ and the heat capacity $C[\mathrm{~J} /(\mathrm{g} \cdot \mathrm{K})][9-13]$ for solid nitrogen. the heat capacity [9-13]. The curve $a(T)$ is monotonic, although the dependence $k(T)$ displays a sharp maximum. The $a(T)$ curve shows a jump at the temperature of $\alpha-\beta$ phase transition. Unlike the case of oxygen, no plateau in the area of liquid helium temperatures is observed.

The temperature dependences of the thermal diffusivity, thermal conductivity [6], density [9-13], and heat capacity [9-13] for solid carbon monoxide are presented in Fig. 3. All curves are monotonous, except for the thermal conduction curve. In the given temperature range the value of the thermal diffusivity of solid carbon monoxide varies by 4 orders of magnitude.

Figure 4 shows the temperature dependences of the thermal diffusivity, thermal conductivity [7], density [9-13], and heat capacity [9-13], of solid nitrous oxide. The curves $a(T), \rho(T), C(T)$ are monotonic. The value of $a(T)$ varies more than 5 orders below $60 \mathrm{~K}$.

Figure 5 shows the temperature dependences of $a(T)$, as well as that of thermal conductivity [8], density [9-13], and heat capacity [9-13] for solid carbon dioxide. The curves $a(T), \rho(T), C(T)$ are monotonous.

Figure 6 shows the thermal diffusivity curves for $\mathrm{N}_{2}, \mathrm{CO}$, $\mathrm{N}_{2} \mathrm{O}, \mathrm{CO}_{2}$ and $\mathrm{O}_{2}$ cryocrystals. It was found that the thermal diffusivity for simple molecular cryocrystals vary by more than 4-6 orders of magnitude in the temperature range from $1 \mathrm{~K}$ up to their triple points. Contrary to the case of solid $\mathrm{O}_{2}$, the curves $a(T)$ for solid $\mathrm{N}_{2}, \mathrm{CO}, \mathrm{N}_{2} \mathrm{O}$ and $\mathrm{CO}_{2}$, do not display any plateau below $4 \mathrm{~K}$. As mentioned above, the plateau in the case of solid oxygen exists because in this temperature range both the heat capacity and the thermal conductivity have the same cubic dependence on temperature

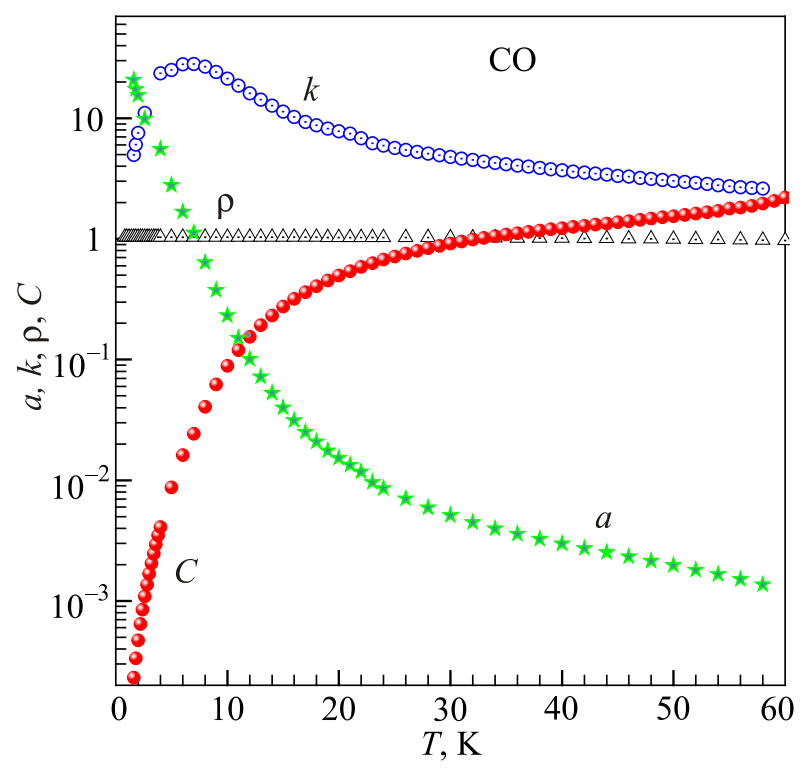

Fig. 3. (Color online) Temperature dependences of the thermal diffusivity $a\left[\mathrm{~cm}^{2} / \mathrm{s}\right]$, the thermal conductivity $k[\mathrm{~mW} /(\mathrm{cm} \cdot \mathrm{K})]$ [6], the density $\rho\left[\mathrm{g} / \mathrm{cm}^{3}\right][9-13]$ and the heat capacity $C$ $[\mathrm{J} /(\mathrm{g} \cdot \mathrm{K})][9-13]$ for solid carbon monoxide. 


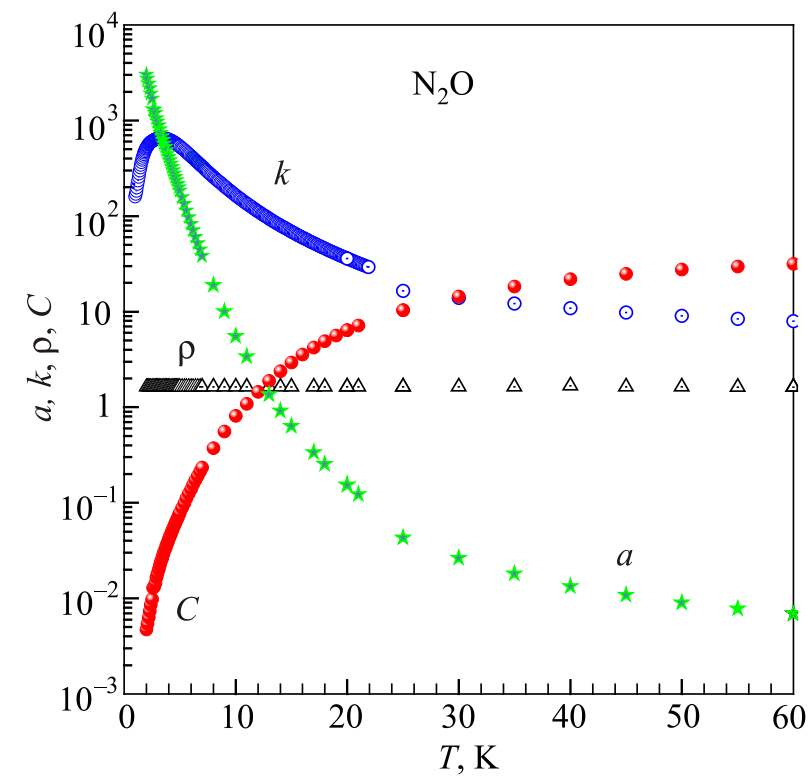

Fig. 4. (Color online) Temperature dependences of the thermal diffusivity $a\left[\mathrm{~cm}^{2} / \mathrm{s}\right]$, the thermal conductivity $k[\mathrm{~mW} /(\mathrm{cm} \cdot \mathrm{K})][7]$, the density $\rho\left[\mathrm{g} / \mathrm{cm}^{3}\right][9-13]$ and the heat capacity $C[\mathrm{~J} /(\mathrm{g} \cdot \mathrm{K})][9-13]$ for nitrous oxide cryocrystal.

while the density weakly depends on temperature. For the crystals of the nitrogen group, the plateau should be shifted to lower temperatures where the thermal conductivity as a function of temperature will obey the cubic dependence.

Let us consider the temperature dependences of the equalization times for these cryocrystals. The ratio of temperature to equalization time $(\tau)$ is proportional to the ratio of temperature to the square of the characteristic crystal

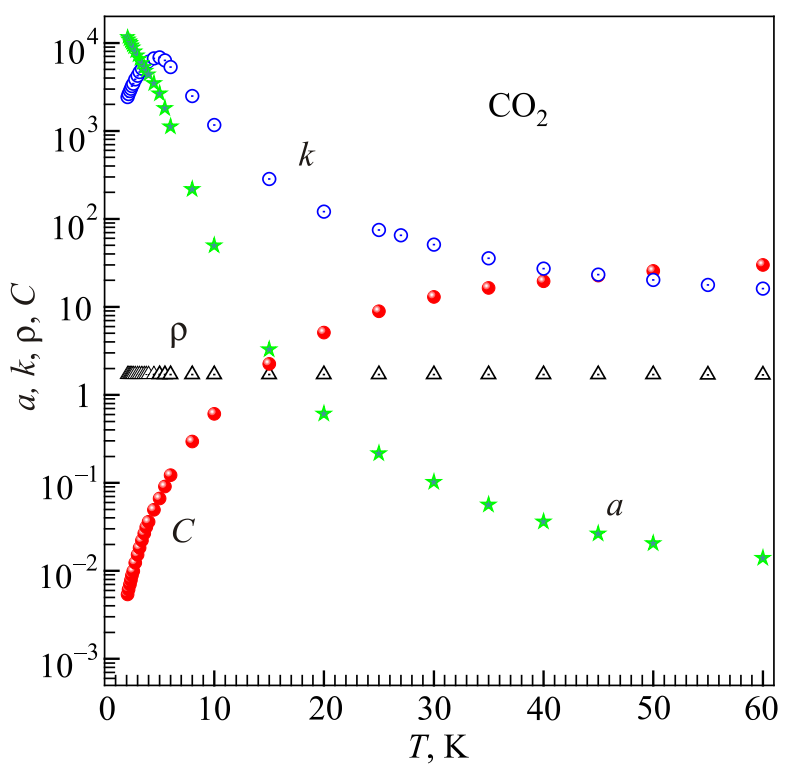

Fig. 5. (Color online) Temperature dependences of the thermal diffusivity $a\left[\mathrm{~cm}^{2} / \mathrm{s}\right]$, the thermal conductivity $k[\mathrm{~mW} /(\mathrm{cm} \cdot \mathrm{K})][8]$, the density $\rho\left[\mathrm{g} / \mathrm{cm}^{3}\right][9-13]$ and the heat capacity $C[\mathrm{~J} /(\mathrm{g} \cdot \mathrm{K})][9-13]$ for solid carbon dioxide.

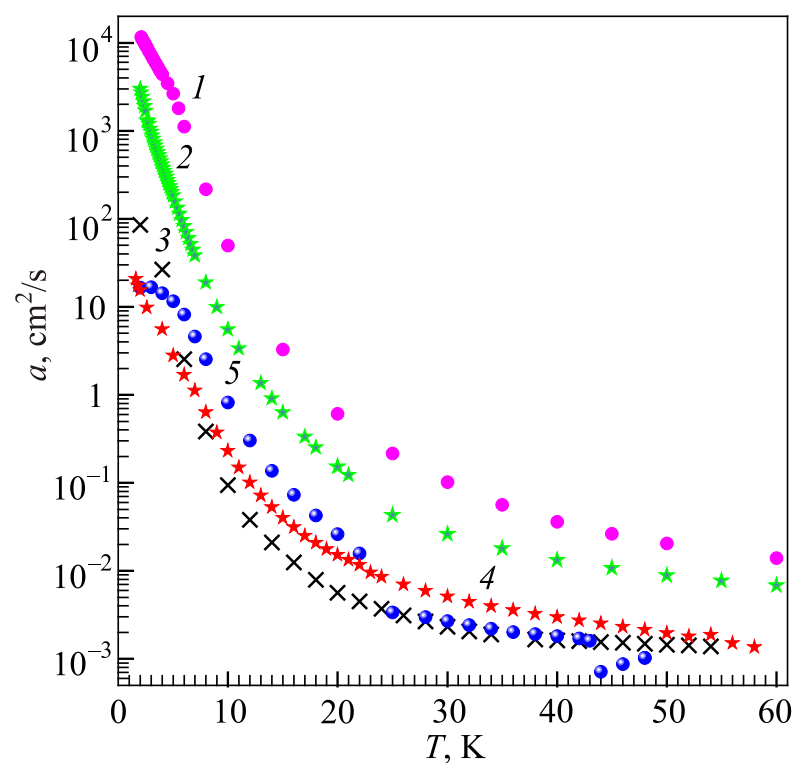

Fig. 6. (Color online) Temperature dependences of the thermal diffusivity for cryocrystals $\mathrm{CO}_{2}(1), \mathrm{N}_{2} \mathrm{O}(2), \mathrm{N}_{2}$ (3), $\mathrm{CO}(4), \mathrm{O}_{2}(5)$.

size $\left(R^{2}\right): T / \tau \propto a T / R^{2}$, whence the equalization time $\tau \propto R^{2} / a$.

As an illustration, for the comparison purpose we calculated the temperature dependences of the equalization time in solid oxygen and in crystals of the nitrogen group for arbitrary taken the crystal size of $1 \mathrm{~cm}$.

The obtained dependences were shown in semi-log scale in Fig. 7. In the case of oxygen at low temperatures, the equalization time is almost temperature independent. Above liquid helium temperatures, the curve increases with temperature. At $\alpha-\beta$ phase transition, a jump of approximately

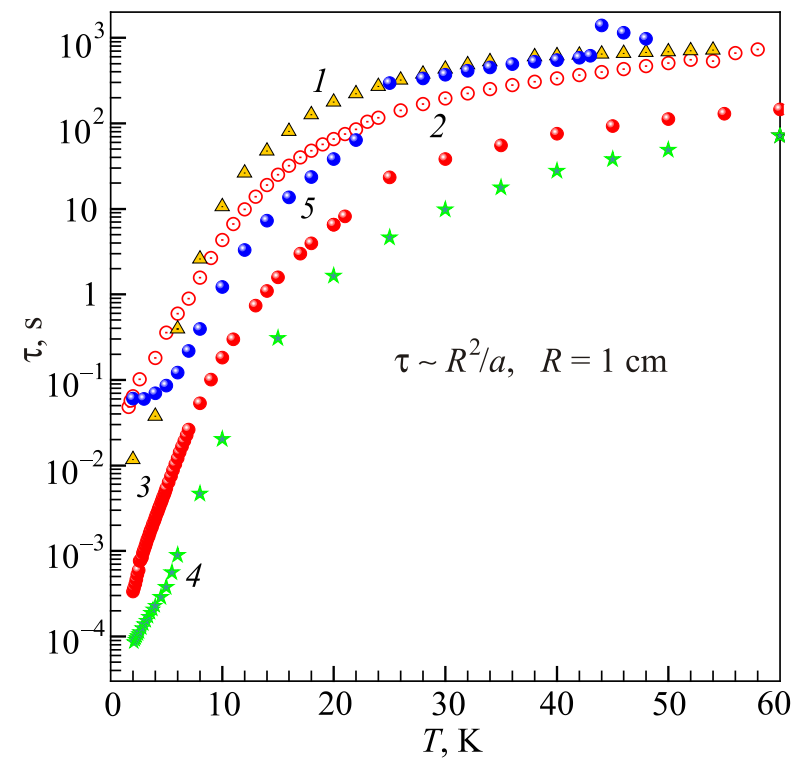

Fig. 7. (Color online) Temperature dependences of the equalization times in cryocrystals $\mathrm{N}_{2}(1), \mathrm{CO}(2), \mathrm{N}_{2} \mathrm{O}(3), \mathrm{CO}_{2}(4), \mathrm{O}_{2}(5)$. 
$370 \%$ is observed. In $\beta$ phase of oxygen crystal the parameter $R^{2} / a$ keeps increasing with temperature. During the $\beta-\gamma$ transition, the equalization time increases abruptly by more than $120 \%$. Finally, in the $\gamma$ phase of solid oxygen the equalization time decreases with increasing temperature.

The equalization time curves for the crystals of solid nitrogen group are monotonous, with the exception of the vicinity of phase transitions. The range of change of equalization times for the temperatures spanning from $1 \mathrm{~K}$ to the triple points is more than 4-6 orders of magnitude.

In conclusion, the temperature dependences of the thermal diffusivity of simple molecular cryocrystals $\mathrm{O}_{2}$, $\mathrm{N}_{2}, \mathrm{CO}, \mathrm{N}_{2} \mathrm{O}$ and $\mathrm{CO}_{2}$ have been analyzed. The thermal diffusivity varies in the range of more than 4-6 orders of magnitude in the temperature area from $1 \mathrm{~K}$ up to their triple points, and in the phase transition regions displays the jumps. In the case of solid oxygen, the temperature dependence of the thermal diffusivity reveals a nonmonotonic character and goes to a plateau below $4 \mathrm{~K}$. The plateau for the cryocrystals of the nitrogen group is shifted to lower temperatures. The thermal diffusivity decreases with increasing temperature. However, in $\gamma$ phase of solid oxygen, the coefficient of thermal diffusivity increases with temperature.

1. V.P. Isachenko, V.A. Osipova, and A.S. Sukomel, Heat Transfer, Energy, Moscow (1969) (in Russian).

2. L.D. Landau and E.M. Lifshits, Theoretical Physics, Vol. 7, Theory of Elasticity, Science, Moscow, Main editorial board for physical and mathematical literature (1987) (in Russian).

3. A. Jeżowski, P. Stachowiak, V.V. Sumarokov, J. Mucha, and Yu.A. Freiman, Phys. Rev. Lett. 71, 97 (1993).

4. Yu.A. Freiman, A. Jeżowski, P. Stachowiak, V.V. Sumarokov, and J. Mucha, Fiz. Nizk. Temp. 22, 194 (1996) [Low Temp. Phys. 22, 148 (1996)].

5. P. Stachowiak, V.V. Sumarokov, J. Mucha, and A. Jeżowski, Phys. Rev. B 50(1), 543 (1994).

6. P. Stachowiak, V.V. Sumarokov, J. Mucha, and A. Jeżowski, J. Low Temp. Phys. 111, 379 (1998).

7. P. Stachowiak, V.V. Sumarokov, J. Mucha, and A. Jeżowski, Phys. Rev. B 67, 172102 (2003).

8. V.V. Sumarokov, P. Stachowiak, and A. Jeżowski, Fiz. Nizk. Temp. 29, 603 (2003) [Low Temp. Phys. 29, 449 (2003)].

9. Cryocrystals, B.I. Verkin, A.F. Prikhotko (eds.), Kiev, Naukova Dumka (1983) (in Russian).

10. Properties of the Condensed Phases of Hydrogen and Oxygen, Handbook, B.I. Verkin et al. (eds.), Naukova Dumka, Kiev (1984) (in Russian).

11. Handbook of Properties of Condensed Phases of Hydrogen and Oxygen, B.I. Verkin (ed.), Hemisphere Publ. Corp., New York (1990).

12. Physics of Cryocrystals, V.G. Manzhelii, Yu.A. Freiman, M.L. Klein, and A.A. Maradudin (eds.), AIP (1997).
13. Structure and Thermodynamic Properties of Cryocrystals, Handbook, V.G. Manzhelii, A.I. Prokhvatilov, V.G. Gavrilko, and A.I. Isakina, Begell House, Inc. Publishers, New York, Wallingford, UK (1998).

\section{Температуропровідність молекулярних кріокристалів}

\section{В.В. Сумароков, А. Jeżowski, P. Stachowiak, Ю.О. Фрейман}

Досліджено низькотемпературну температуропровідність молекулярних кріокристалів $\left(\mathrm{O}_{2}, \mathrm{~N}_{2}, \mathrm{CO}, \mathrm{N}_{2} \mathrm{O}\right.$ i $\left.\mathrm{CO}_{2}\right)$. Температуропровідність цих кристалів змінюється більш ніж на 4-6 порядків в області температур від 1 К до їх потрійних точок. В області фазових перетворень спостерігаються стрибки температуропровідності. Виявлено, що температуропровідність твердого кисню $є$ немонотонною. Нижче 4 К на температурній залежності спостерігається плато, яке обумовлено тим, що як теплоємність, так і теплопровідність в цьому температурному діапазоні мають кубічну температурну залежність. Для кріокристалів азотної групи подібне плато зміщується в бік більш низьких температур. Вивчено температурну залежність часів вирівнювання температури для цих кристалів.

Ключові слова: теплопровідність, температуропровідність, питома теплоємність, густина, молекулярні кріокристали.

\section{Температуропроводность молекулярных криокристаллов}

\section{B.B. Сумароков, A. Jeżowski, P. Stachowiak, Ю.А. Фрейман}

Исследована низкотемпературная температуропроводность молекулярных криокристаллов $\left(\mathrm{O}_{2}, \mathrm{~N}_{2}, \mathrm{CO}, \mathrm{N}_{2} \mathrm{O}\right.$ и $\left.\mathrm{CO}_{2}\right)$. Температуропроводность этих кристаллов изменяется более чем на 4-6 порядков в области температур от 1 К до их тройных точек. В области фазовых переходов наблюдаются скачки температуропроводности. Обнаружено, что температуропроводность твердого кислорода является немонотонной. Ниже 4 К на температурной зависимости наблюдается плато, обусловленное тем, что как теплоемкость, так и теплопроводность в этом температурном диапазоне имеют кубическую температурную зависимость. Для криокристаллов азотной группы подобное плато смещается в сторону более низких температур. Изучена температурная зависимость времен выравнивания температуры для этих кристаллов.

Ключевые слова: теплопроводность, температуропроводность, удельная теплоемкость, плотность, молекулярные криокристаллы. 